\title{
The Impact of Family / School-Based Problem Solving Training on Problem-Solving Styles of Elementary Students
}

\author{
Keivan Kakabaraee*1 \\ 1. Associate Professor, Department of Psychology, Kermanshah Branch, Islamic Azad University, Kermanshah, Iran \\ Received: January 31, 2018 \\ Accepted: May 21, 2018
}

\begin{abstract}
:
Background and Purpose: Problem solving is one of the structured cognitive programs that provides a range of efficient responses to deal with the problematic situations of life. The purpose of this study was to determine the effect of family / school-based problem solving training on problem-solving styles of elementary students.

Method: The present study was an experimental research with pretest, post-test, follow up design with a control group. A sample of 120 students were selected using random sampling method and were randomly assigned to experimental (60 subjects) and control (60 subjects) groups. After 10 two-hour sessions of education for the parents and teachers, the experimental group received a family/school oriented problem-solving program for three months. A short version of the social problem solving (D'Zurilla, Nezu \& Maydeu-Olivares, 2004) was used to collect data in three forms of students, parents, and teachers.

Results: According to the reports by the students (participants), parents, and teachers, the results showed that in the experimental group, there was a significant difference between pretest and posttest scores on the subscales of problem solving, but there was no significant difference between the scores of posttest and follow-up on the subscales of problem solving $(\mathrm{P} \leq 0.05)$

Conclusion: Family/school problem-solving training is effective on student's problem solving styles, so using this method is important as a preventive program for parents and teachers to adopt an effective problem-solving style for students.
\end{abstract}

Keywords: Family/school oriented problem solving, problem solving styles, elementary students

Citation: Kakabaraee K. The impact of family / school-based problem solving training on problem-solving styles of elementary students. Quarterly Journal of Child Mental Health. 2019; 6(1): 14-27.

*Corresponding author: Keivan Kakabaraee, Associate Professor, Department of Psychology, Kermanshah Branch, Islamic Azad University, Kermanshah, Iran.

Email: Kakabraee@gmail.com $\quad$ Tel: (+98) 83- 37243181 


\section{تأثير آموزش حل مسئله خانواده/ مدرسهمحور بر سبكهاى حل مسئله دانش آموزان دوره ابتدايى}

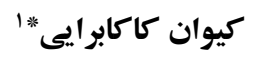

1. إنشيار كروه روانشناسى، واحد كرمانشاه، دانشخاه آزاد اسلامى، كرمانشاه، ايران

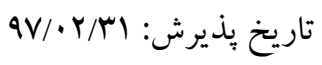

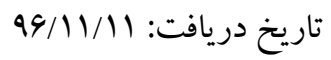

زمينه و هدف: حل مسـئله، يكى از برنامه هاى سـاختاريافته شـناختى است كه طيفى از ياسخ هاى كار آمد را براى مقابله با موقعيتهاى

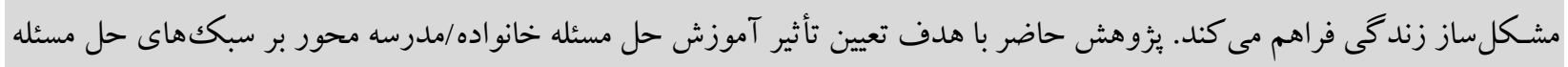
دانش آموزان انجام شد.

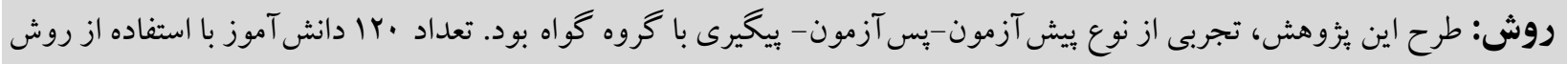

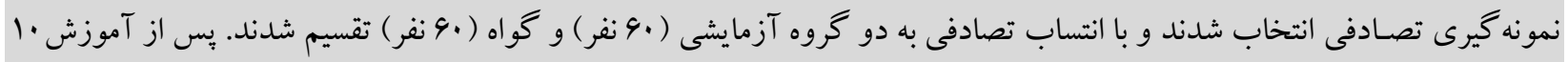

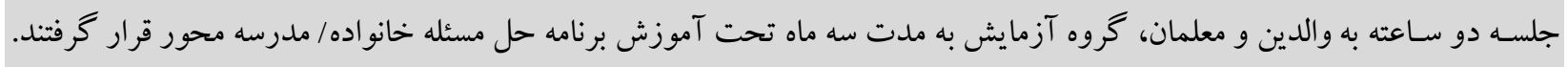

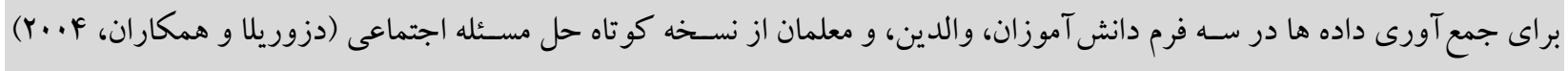
استفاده شد.

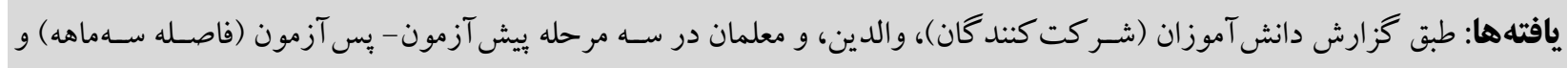

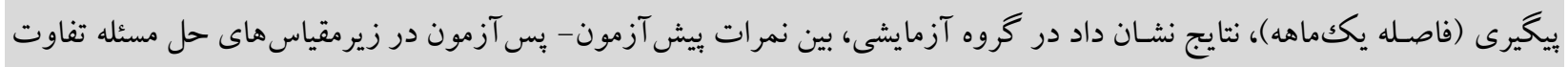

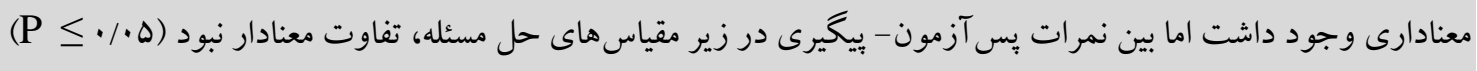

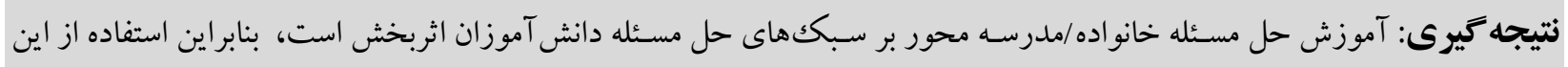

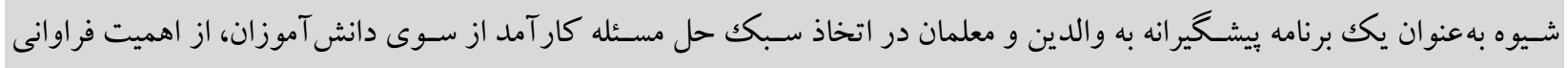
برخوردار است. كليدوازهها: حل مسئله خانو اده/ مدرسهمحور، سبكهاى حل مسئله، دانش آموزان دوره ابتدايى 
فعالانه در به كار بستن راهبردها و روشهاى حل مسـئله است اما

مقدمه

اين سـعى و تلاشها، تكانشسى، شـتابززده، و بدون تأمل اسـت. وجه مشخصه سبك اجتنابى نيز اهمال كارى، طفره رفتن، انفعال،

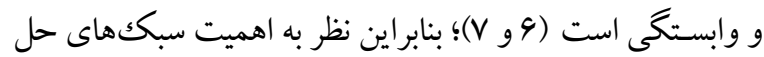

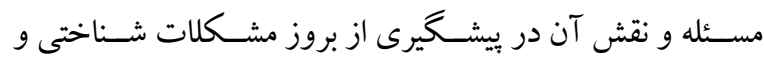
رفتـارى كودكـان و نوجوانـان، ارائه برنـامـهـاى مدون آموزش خانواده/مدرسـمحور بر اساس مدل حل مسئله در جهت ارتقاى

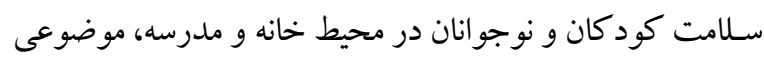
ضرورى تلقى مىشود (هو 9).

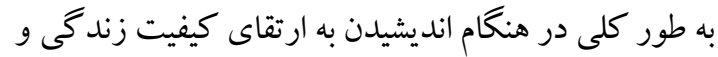
تغيير رفتار كود كان و نوجوانان، مىتوان بر دو گسـتره خانو اده و هو مدرسـه متمركز شد. بيشينه يُزوهشى مربوط به عو امل ارتقادهنده

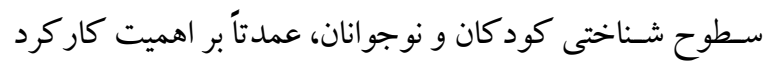

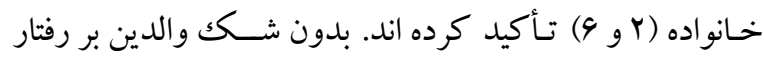

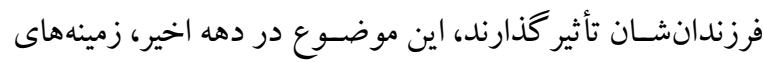
مختلفى براى يُووهش و طر احى برنـامـهاى مداخله حل مســـئله خانو ادهمحور بهمنظور بهبود مهارتهاى ميانفردى فر اهم آورده

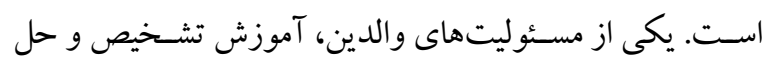

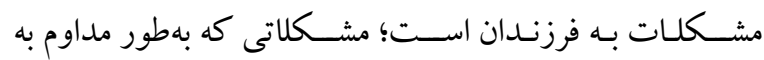
شكلهاى مختلف و از ساده تا بيجيجيده در زندگى ظاهر مى شوند. در اين روش والـدين بـدون آن كه به اعتمادبهخود فرزندان خود

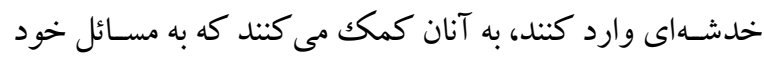
بيند يشند، راهحل هاى مختلفى براى آن بيابند، و با انتخاب بهترين

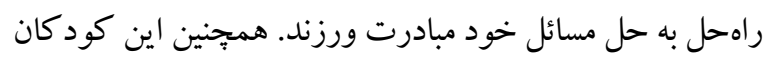

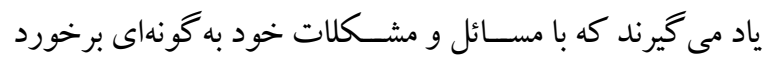
كنند كه دجار اضطراب نشوند و با شكستهاى احتمالى برخورد مناسبى داشته باشند (1). علاوه بر خانو اده، مدرسه نيز نقش بسيار مهمى در فرايند اجتماعى كردن كود كان و نوجوانان ايفا مى كند

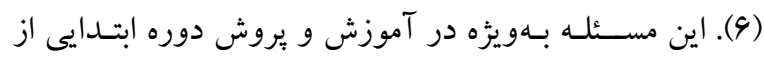

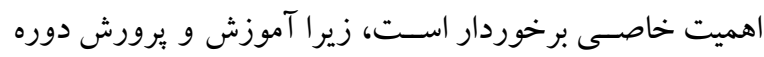

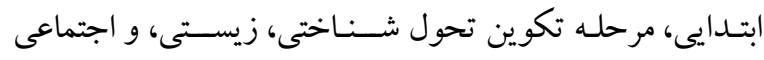
در متون روانشـناسى تحولى، كودكى بهعنوان يكى گستره سنى

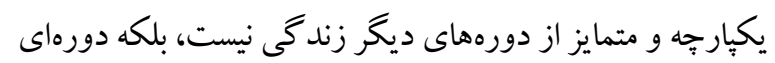

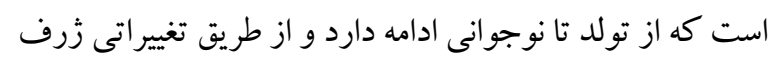

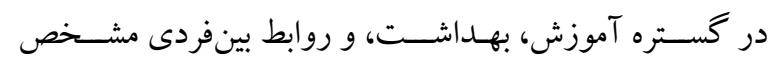

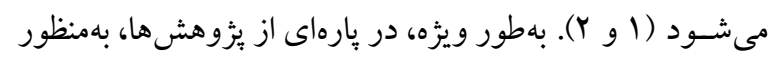

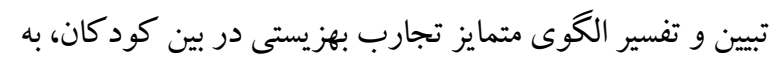

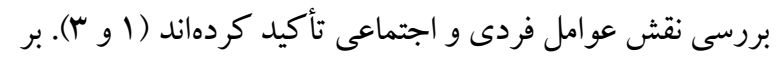

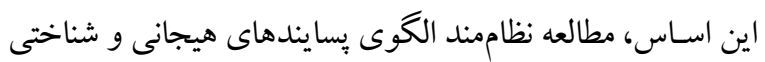

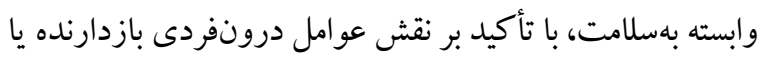

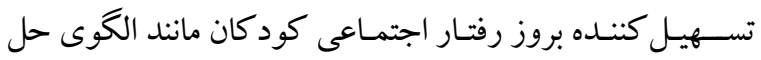

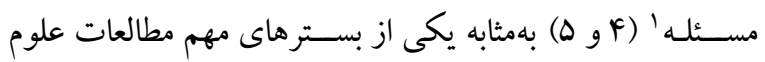
شناختى، يكك اولويت يزوهشى انكارنايذير تلقى مى شود.

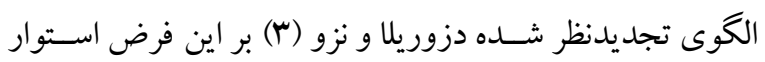

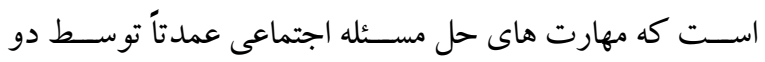
فرايند كلى نسبتاً مستقل تعيين مىشوند: () روى آوردن به مسئله و Y) سبك حل مسئله. روى آوردن به مسئله، فر ايندى فر اشناختى

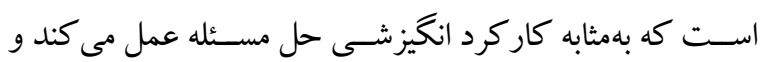

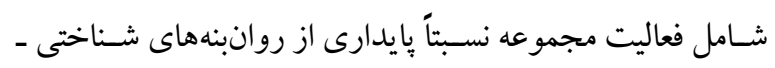

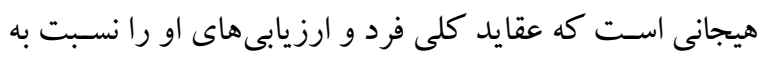

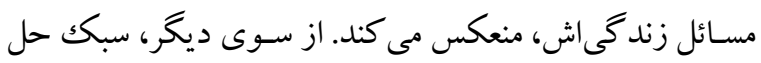

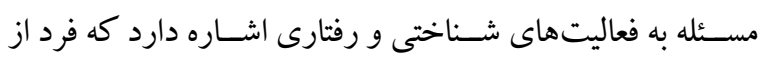

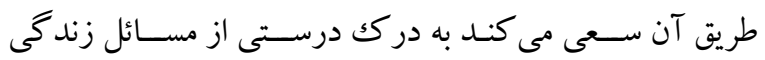
روزمرهاش رسـيده و روشها و راهحلهاى مؤثرى براى مقابله با

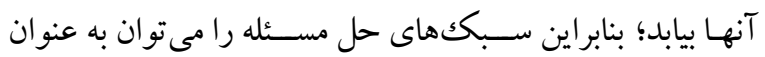

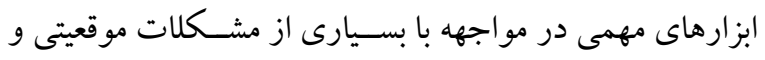
حل آنها در نظر داشـت كه شامل حل منطقى مسئله، سبكك غير مهري

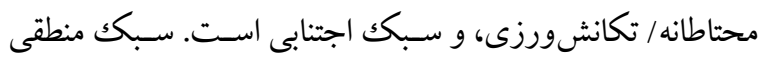
حل مسئله، مهارت سازندهاى است كه به كاربرد منطقى، آكاهانه

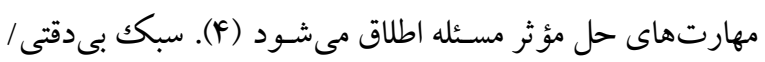

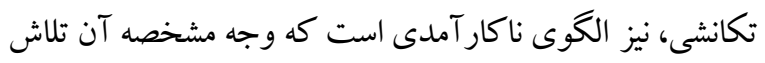

\section{Problem Solving}


دوره 19 هفتـهاى، آموزش دادنـــ نتـايج نشــان داد كـه همـه

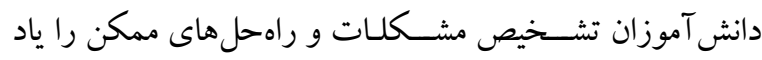

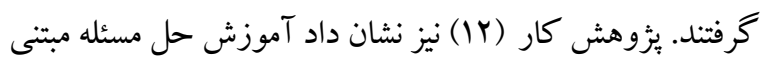

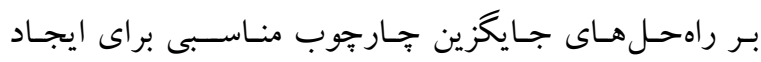

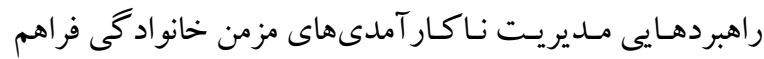
خو اهد آورد. اوستاد (سا) در يُزوهش ديخرى نشان داد مداخله شــــاختى مبتنى بر حل مســـئه در خانو اده با كاهش مشــكلات

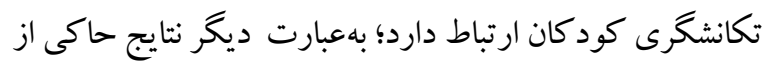

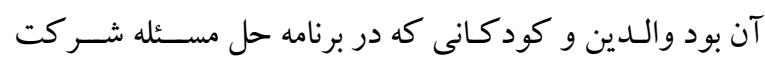
كردهانـد، بـهور معنادارى كاهش رفنارهاى تخريبى كود كان و افزايش كار آمدى والدين رادر ارتباط با كود كانشـان، كزارش

در همين راســـا، نتـايج يثزوهش هـاى متعـدد ديخر بر روى

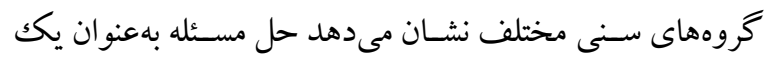
مهارت در شــناسـايى مشـكلات و راهحل هاى بالقوه، به افر اد كمك كرده و باعث مى شـود راهحل هاى ممكن، بهدقت مطالعه شـده و مناسـب ترين آنها با شـــايط فرد، انتخاب و اجرا شـود و درنهايـت در موقعيـتهـاى مختلفى همجِون مشــكل گشــايى،

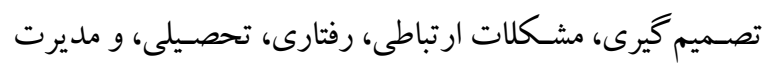

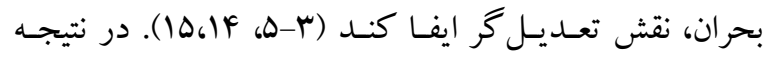
كاربست آموزش حل مسئله از طريق والدين و معلمان يا به طور مسـتقيم از طريق كودكان و نوجوانـان بر كاهش رفتارهايى از جمله تكانشــرى، گوشــهـ گيرى، كمرويى و بهبود عملكرد

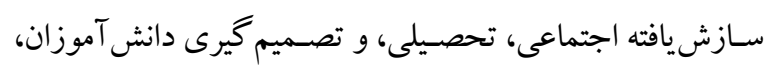

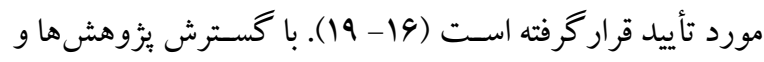
مبانى نظرى مرتبط با حل مسـئله كه به مهمترين آنها اشـاره شد،

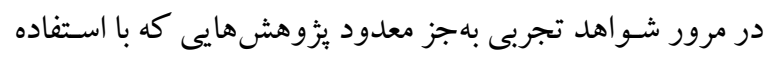

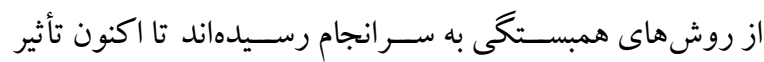
همزمان آموزش حل مسئله خانواده/مدرسهمحور بر سبككهاى حل مسـئله (منطقى، تكانشى، و اجتنابى) و فر ايند بييخيرى برنامه

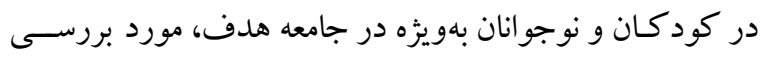
قرار نكر فته استـ، بنابراين بررسى اين مسئله كه برنامه حل مسئله
دانش آموزان بوده و موجـب شـكوفـايى اسـتعـداد و افزايش عسملكرد روانى، اجتمـاعى، و تحصـيلى آنـان مىشـود (V) از آنجايى كه حضور مداوم دانش آموزان در محيطهاى آموزشى دهى

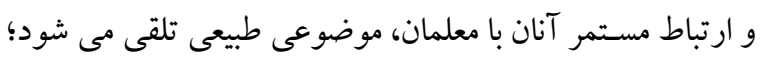

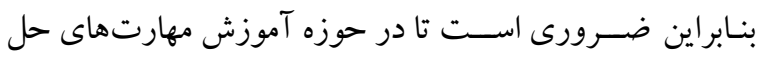
مسئله، كار آمد شوند (^و 9). بايد اظهار كرد كه امروزه با توجه به وضـعيت زندكى اجتماعى و آسـيبهاى بيش رو، مهم ترين

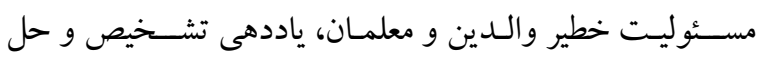

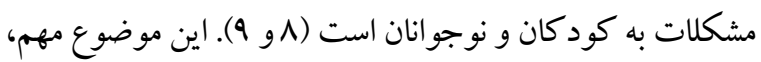

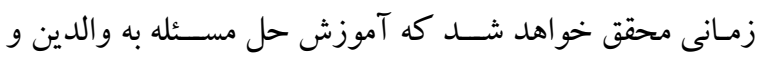
معلمان همسـو و در يكك راستا قرار گيرد، كه يزوهش حهو حاضر در واقع در تأييد همين موضوع انجام شده است. شـواهد يزووهشى بسـيارى وجود دارد كه تأثير آموزش حل

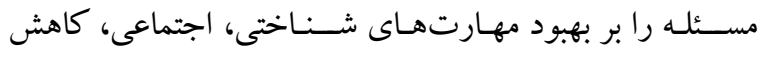

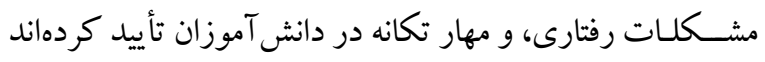

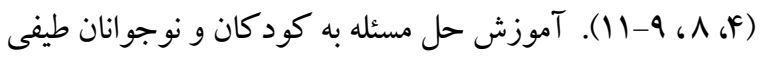
از ياسـخهاى بديل و بالقوه را براى مقابله با شر ايط مشكل آفرين

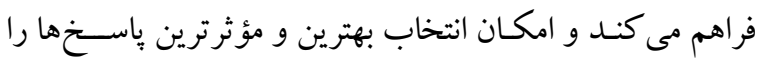

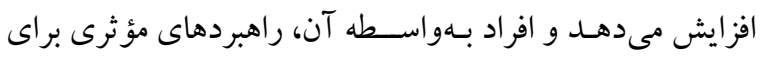

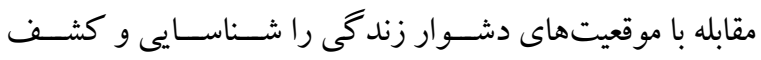

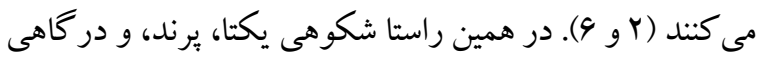
در يُزوهشى نشـان دادند كه آموزش روش حل مسئله به والدين

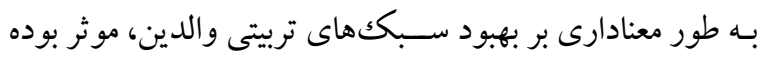

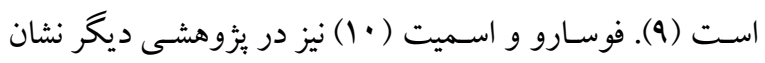

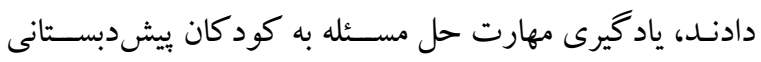
كمكك مى كند تا آنها در هنكام رويارويى با رويدادهاى تنش آور زنـدگىى، احسـاس تســلط كنتـد و در كك منطقى از مســئله و راهحلهاى موجود، از خود نشـان دهند.كوته و همكاران (1) نيز در يُوهشــى با طرح تككبر رسـى با خند خط پايه، از طريق

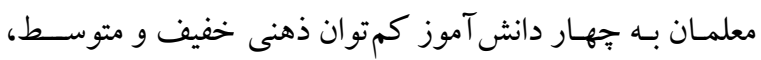
راهبردهاى حل مسـئله، شـامل تشـخيص مشكلات و راهحل هاى

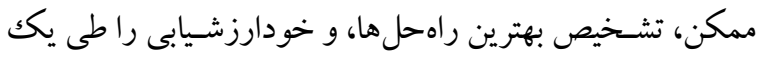


داشـتن در بايه تحصـيلى جهارم تا شـشــم دبسـتان ، Y) تعهد و همكارى لـازم والـدين و معلمان. ملاككهاى خروج شــامل: () ) داشـتن نوعى بيمارى بزشـكى كه فرد را به جسـتجوى فورى درمان وادار سـازد، Y) عدم تمايل و رضـايت معلمان، والدين، و دانش آموز در شركت فعال در كار گاه، بود. الف) ابزار يزووهش: نسـخه كو تاه فهرسـت تجديدنظر شــده

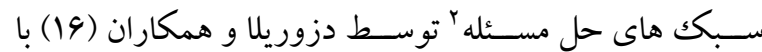
هدف ارزيابى تو انيى مهارتهاى حل مسئله اجتماعى طر احى

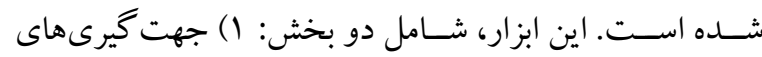
مسئله (مثبت و منفى) و Y) سبك هاى حل مسئله كه مورد نظر يُزوهش حاضـر بود و شـامل: () سـبكك منطقى حل مســئه،r)

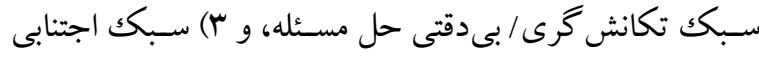

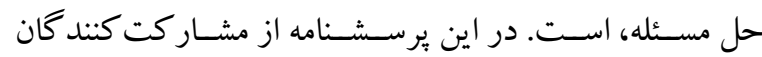
درخواسـت مى شـود تا ياسـخ صـحيح را بر روى يكك مقياس ئرس

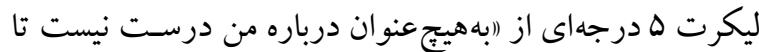
درباره من كاملاً درست است) انتخاب كنند. نتايج مطالعه سى يو و شكك (IV) نشـان داد كه اين نسـخه كو تاه ها سـؤ الى در جمعيـت كودكـان و نوجو انـان از روايى و يـايـايى قابل قبولى ئى برخوردار اسـت. سـؤالهاى سه بخش اين مقياس شامل: سبكك

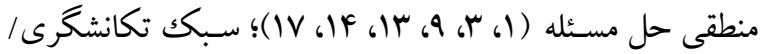

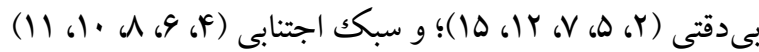

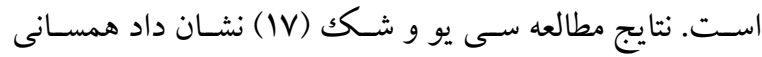

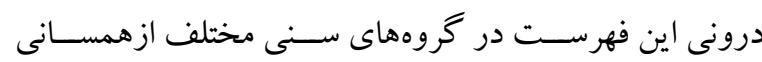

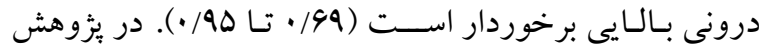
حاضر نيز، ضرايب آلفاى كرونباخ بر اى عامل هاى سبك منطقى حل مسئله، سبكك تكانشى/ بـدقتى حل مسئله، و سبك اجتنابى

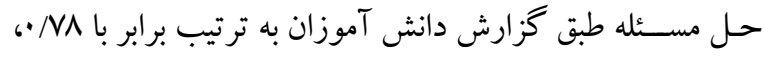

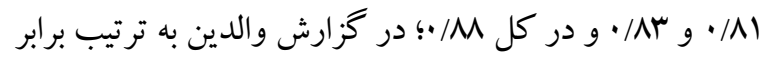

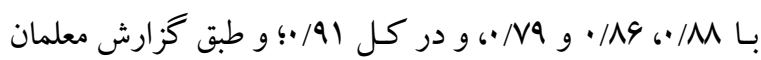

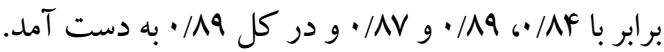

خانو/د/مدرسهمحور تا جه ميزان راهبردهاى حل مسئله را تعديل مى كند؟ را مىتوان يكك ضــرورت يُزوهشسى انكارنايذير تلقى كرد. بر اين اســاس هـدف يثوهش حاضــر، مطالعه يِيامدهاى

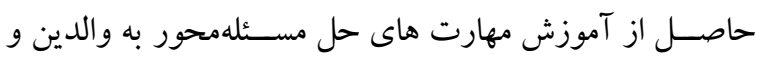

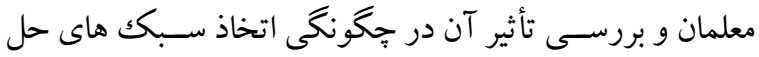
مسئله كار آمد از سوى دانش آموزان است.

روش يُزوهش حاضـر با توجه به هدف، كاربردى و از نظر شيوه اجرا،

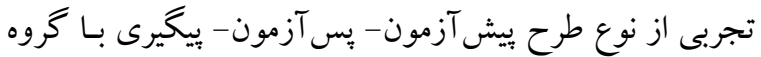

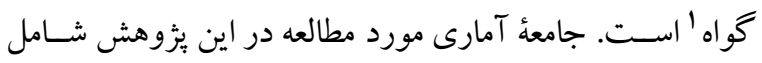
تمامى دانش آموزان دختر و پِر پِايههاى جِهارم تا ششم مدارس ابتدايى دولتى عمومى شـهر كرمانشـاه در سال تحصيلى 99 - 90 اسـت. گروه نمونه با استفاده از روش نمونه گيرى تصادفى شامل

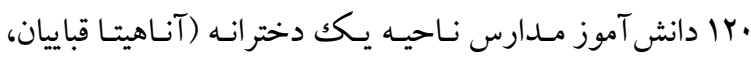
سيمين دخت راى) و بسـرانه (شاهد شيرزادى، منوجهر شريفى)

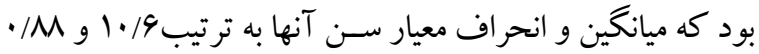
بود. در اين بثزوهش گروه نمونسه بـا تفكيكك يـايه تحصـيلى و

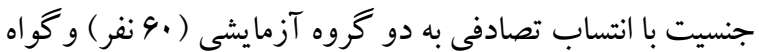

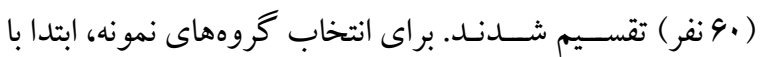

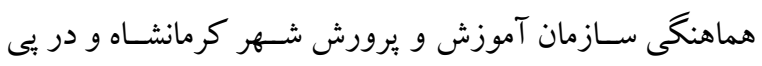
فراخوان مسئولان يادشده در زمينه معرفى كار گاههاى حل مسئله خانو اده/ مدرسـهمور براى والدين و معلمان انجام شـد. ســس مسئولان كار كاهها در طى يكك جلسه آموزشى، برنامه كار گاهها

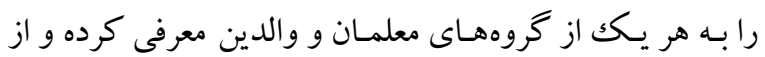

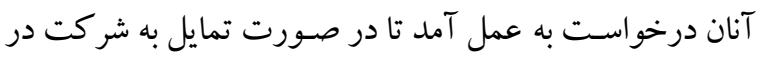

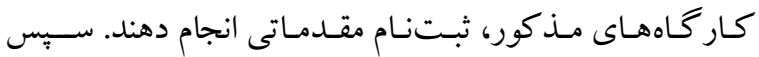
دانش آموزانى كه والدين و معلمان آنها ثبتنام مقدماتى كرده و

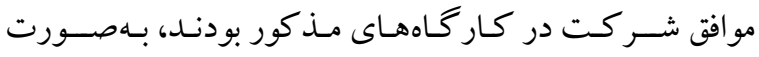
نمونه گيرى تصادفى ساده، انتخاب و ثبت نام نهايى به عمل آمد. ملاككهاى ورود عبارت بودند از: () سـن · ا تا با سـال و قرار 
مفاهيم كلى فوق رادر قالب بيش از •9 طرح درس ارائه مىدهد

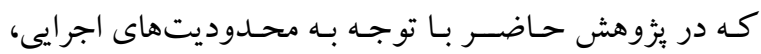

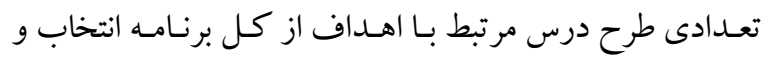

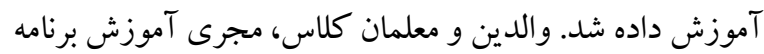
مداخلهاى هسـتند و طى جلسـاتى در مورد برنامه و نحوه اجراى آن، آموزشهاى للازم را دريافت كردهاند. پِ از •ا جلســه دو سـاعته به والدين و معلمين، برنامه مداخله طى سـه ماه در خانه و مدرسـه به صسورت دو جلسـه •ه دقيقهاى در هفته و بهصسورت

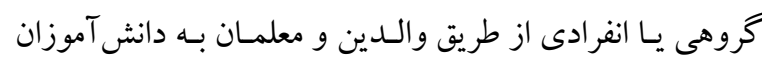

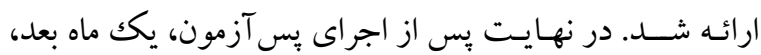

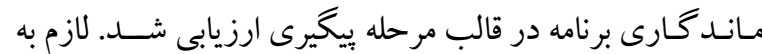

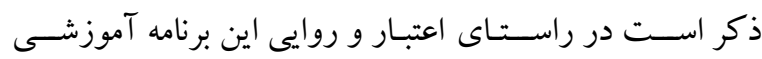

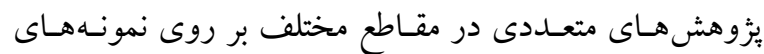
متفاوت ايرانى اجر اشده است (مل 9 و ها). در ادامه در جدول 1 خلاصه محتوا و هدف هر جلسه مداخله ارائه شده است.
ب) بـرنـامـه مــداخلـه: كـارگحاه تربيـت كودكك/ نوجوان

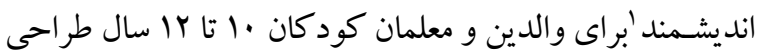
شـده اسـت. هدف اين كار گاه، افزايش مهارتهاى كود كك در برخورد مؤثر بـا مســائل مختلف در خـانه و محيط بيرون خانه اسـت. توجـه اصسلى كـار گحاه بر آموزش والدين و معلمان در اســفــاده از شـيوه كار آمد تعاملى با كودكك و نوجوان در حل مسـائلى است كه در ارتباط با والدين و همسالان براى كودكك و

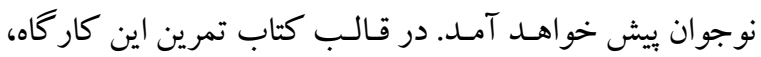

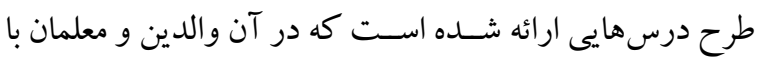

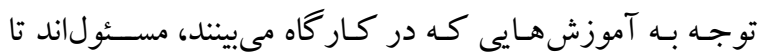

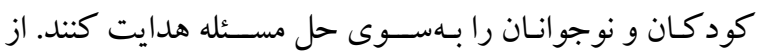

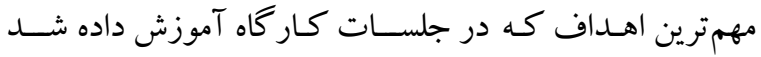

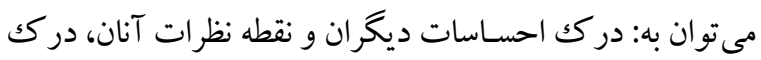
انخيزهها، يافتن راهحل هاى متعدد، در نظر كرفتن عواقب و نتايج، و برنامهريزى متو الى، اشـاره كرد. برنامه حل مســئله مورد نظر،

جدول ا: خلاصه جلسات مداخله

\begin{tabular}{|c|c|c|c|}
\hline تكاليف & 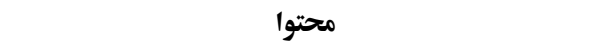 & 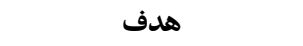 & جلسه \\
\hline بخش كليب ميوه درخت گردو و ارائه & تشريح اهداف كار كاه و بررسى اهميت آن با تاكيد بر جهار شيوه & آشنايى با دوره كودكى & \\
\hline و توضيح بركه تمرين & تربيتى والدين & 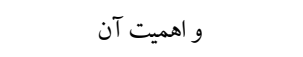 & اول \\
\hline بخش كليب غم فرداى موهوم & 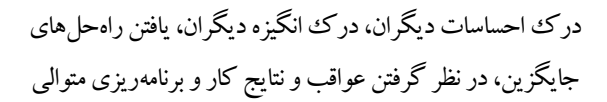 & آشنايى با مهارتهاى حل مسئله و & دوم \\
\hline پِخش كليب رسائل و ارائه جدول & تشريح اهميت شناخت و بيان احساسها در زندگى واقعى در تعامل با & يرداختن به مقوله احساسات & 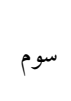 \\
\hline 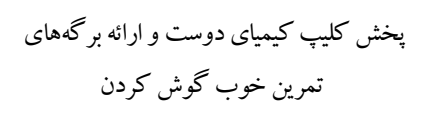 & 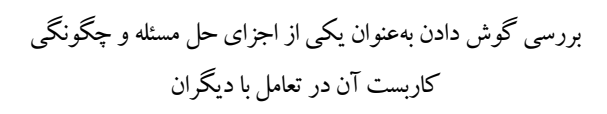 & 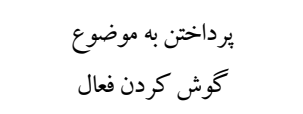 & جهارم \\
\hline 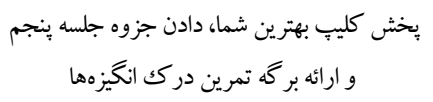 & 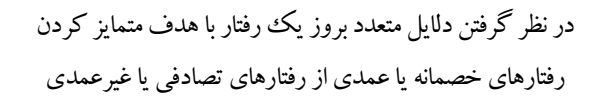 & ير درك اختن به مبحث & 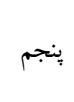 \\
\hline 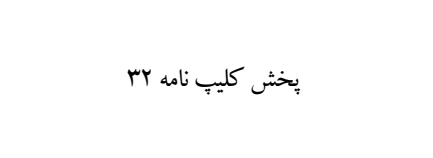 & 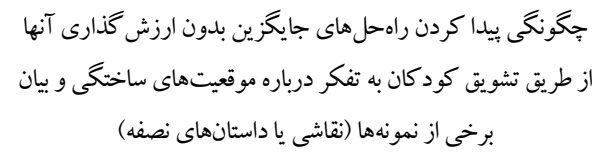 & 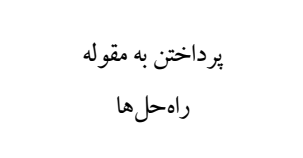 & ششم \\
\hline بخش كليب سينى و ارائه بركه آموزش تفكر & 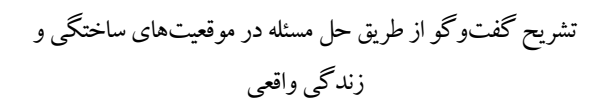 & بر براختن به مبحث & هفتم \\
\hline يخش كليب دو ليمو & 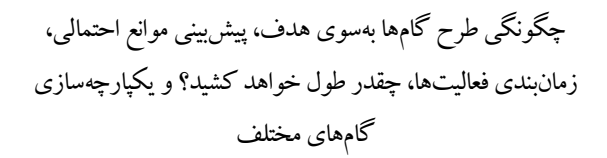 & بر برداختن به مهار & 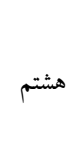 \\
\hline
\end{tabular}




$$
\begin{aligned}
& \text { تمرينهاى تركيبى با تشكيل كروههاى سه نفر } \\
& \text { و ارائه داستانهاى ناقص و تكميل آن }
\end{aligned}
$$

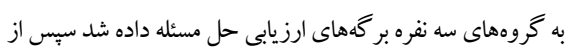

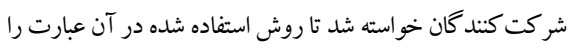

$$
\text { مشخص كند الندان }
$$

$$
\text { مرورى مهارت هاى فرا كرفته شده تاكنون بهوسيله يرس و ياسخ از }
$$

مرور نهايى بر كفت گو به شيوه حل مسئل، جمعبندى و در نهايت

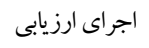

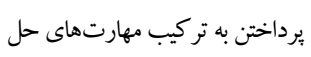

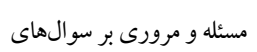

is

مرورى مطالب فرا كرفته

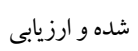

للازم به ذكر است تمامى ملاحظات اخلاقى در اجراى اين

مطالعه رعايت شد. بدين ترتيب ضمن كسب مجوزهاى لازم، به

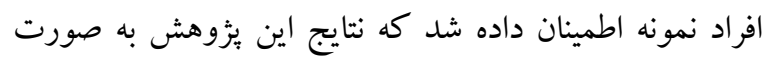
كروهى تحليل مىشود و اطلاعات آنها محرمانه باقى مىماند. همجِين رضايت كتبى از دانش آموزان، والدين، و معلمان آنها نيز كرفته شد.

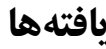

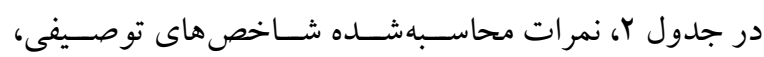

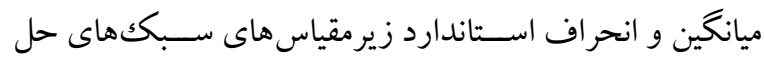

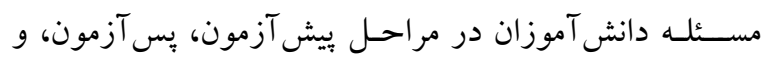

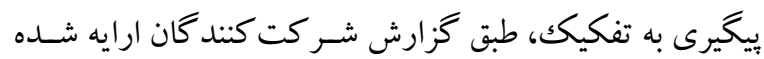

ج) روش اجرا: بعد از تصويب طرح يزوهشى مورد نظر و اخذ

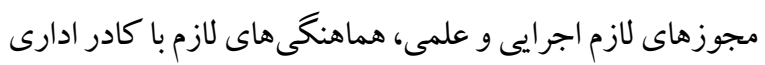

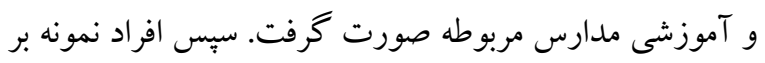
حسب شاخصها و ملاككهايى از قبل تعيينشده، انتخاب شده و در گروههاى آزمايش و گُواه جايدهى شدهاند. در مرحله بعد، برنامه مداخلهاى بر اساس مر احلى كه در بخش قبلى توضيح داده

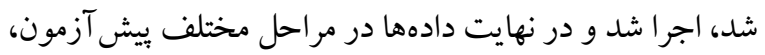
بس آزمون، و وييخيرى جمع آورى شد؛ بدين منظور ابزارهاى

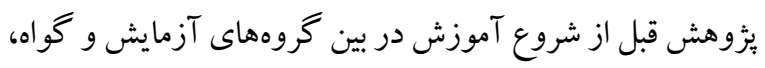

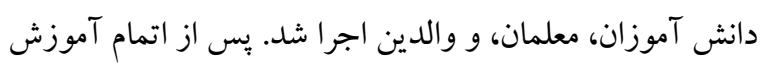
معلمان و والدين، دانش آموزان نيز به مدت سه ماه مداخله حل

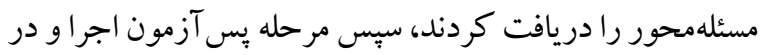
نهايت بعد از يك ماه، مرحله ييخيرى انجام شد.

جدول ז: آمارههاى توصيفى متغير هاى سبك منطقى، سبك تكانشى و سبك اجتنابى بر حسب كروه

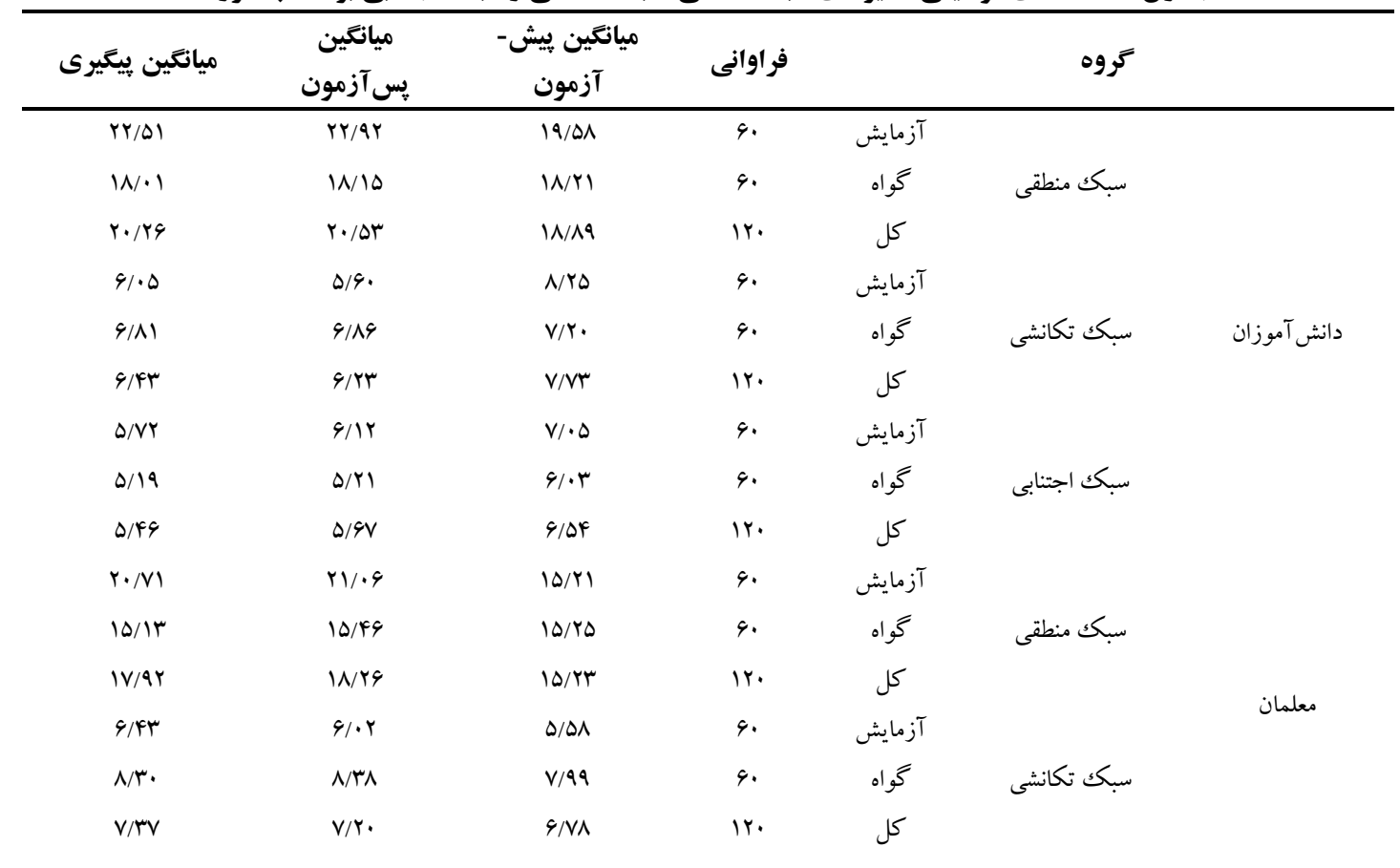




\begin{tabular}{|c|c|c|c|c|c|c|}
\hline $\mathrm{V} / \Lambda \Lambda$ & $\mathrm{V} / \cdot \mathrm{A}$ & $V / 9 \Delta$ & 4. & آزمايش & & \\
\hline $9 / 9 \mathrm{~V}$ & $9 / 91$ & G/VD & 4. & كواه & سبك اجتنابى & \\
\hline 9/9r & $9 / M$ & $\mathrm{~V} / \mathrm{T \Delta}$ & ir. & كل & & \\
\hline$r \cdot 194$ & $r \cdot / V r$ & IV/A. & 4. & آزمايش & & \\
\hline $19 / \pi$. & $19 / 49$ & $19 / 12$ & 4. & كو اه & سبكك منطقى & \\
\hline$M / F A$ & $N / \Delta \Delta$ & $19 / 91$ & ir. & كل & & \\
\hline$V / 9$. & $V / 9 \Lambda$ & $\Lambda / A V$ & 4. & آزمايش & & \\
\hline$\Lambda / T V$ & $N / \mu^{2}$ & $1 / 90$ & 4. & كواه & سبك تكانشى & والدين \\
\hline$\Lambda / I F$ & $\Lambda / Y$. & N/VG & ir. & كل & & \\
\hline $9 / . r$ & 91.9 & $V / Y \Lambda$ & 4. & آزمايش & & \\
\hline $9 / 91$ & G/VD & $9 / 94$ & 4. & كواه & سبك اجتنابى & \\
\hline $9 / \pi \Delta$ & $9 / 41$ & $9 / 99$ & ir. & كل & & \\
\hline
\end{tabular}

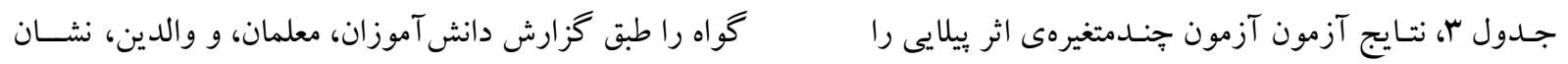

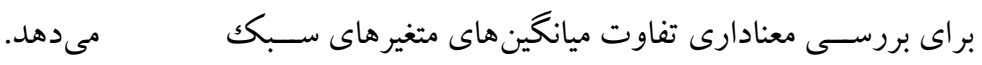
منطقى، سبكك تكانشى، و سبك اجتنابى بين گروه آزمايش و

جدول سا: آماره جندمتغيرى اثر ييلايى براى بررسى معنادارى تفاوت متغيرهاى سبككهاى منطقى، تكانشى، و اجتنابى بين كروه آزمايش و كواه

\begin{tabular}{|c|c|c|c|c|c|}
\hline سطح معنادارى & درجه آزادى خطا & درجه آزادى فرضيه & $\mathbf{F}$ & اثر پيلايى & \\
\hline.$/ \cdot 1$ & $11 \pi$ & $r$ & $11 / 1 F$ & $\cdot /$ YYA & دانش آموزان \\
\hline.$/ \cdot 1$ & $11 \pi$ & $r$ & $\mid r / 1 \Lambda$ & - TFF & معلمان \\
\hline.$/ \cdot 1$ & $11 \pi$ & $r$ & $q / 4 \Delta$ & $\cdot / r \cdot 1$ & 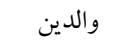 \\
\hline
\end{tabular}

منطقى، سـبك تكانشـى، و سـبك اجتنابى در بين گرووهاى آزمـايش و گواه، تفـاوت معنـادار وجود دارد (ه (P)

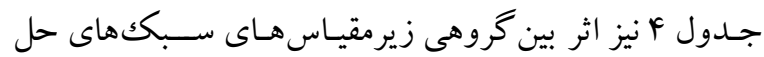
مسئله و آزمون مقايسه بين آزمودنى ها را براى متغيرهاى سبكك منطقى، ســـك تكانشــى، و ســـك اجتنابى طبق گزارش دانش آموزان، معلمان، و والدين را نشان مىدهد.
همان كونه كه در جدول ب مشـاهده مىشود، طبق گزارش دانش آموزان، مقـدار آمـاره اثر بيلايى، ^YYY/• بوده و از لحاظ آمارى در سـطح هـ • معنادار اسـت. طبق گز ارش معلمان نيز مقدار آماره اثر ييلايى، TFF/ · بود و از لحاظ آمارى در سـطح هـ • • معنادار اسـت و همجِنين طبق نظر والدين نيز مقدار آماره

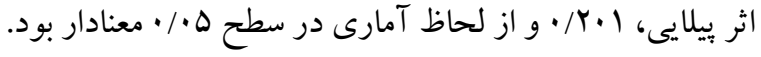
اين يافته ها نشـان مى دهد حداقل در يكى از متغير هاى سـبك

جدول ع: آزمونهاى اثر بين كروهى متغيرهاى سبك منطقى، سبك تكانشى، و سبك اجتنابى بين كروه آزمايش و كواه

\begin{tabular}{|c|c|c|c|c|c|c|}
\hline سطح معنادارى & $\mathbf{F}$ & مجذورات ميانغين & درجه آزادى & متغير وابسته & \multicolumn{2}{|c|}{ منبع تغيير ات } \\
\hline.$/ \cdot 1$ & $r Q / \Gamma \Delta$ & $\$ 99 / 9 V$ & 1 & سبك منطقى & & \\
\hline .1 .11 & $\Delta / v \Delta$ & VN/AY & 1 & سبك تكانشى & كروه & دانش آموزان \\
\hline •/YVG & $1 / r$. & $\mid F / F Y$ & 1 & سبكك اجتنابى & & \\
\hline.$/ .1$ & $F I / \mu r$ & $q 4 \cdot / \Lambda$. & 1 & سبكك منطقى & & \\
\hline$\cdot \cdots v$ & $V / F V$ & $191 / .4$ & 1 & سبك تكانشى & كروه & معلمان \\
\hline .1949 & - & $F / \Lambda$. & 1 & سبكك اجتنابى & & \\
\hline
\end{tabular}




\begin{tabular}{|c|c|c|c|c|c|}
\hline$\cdot / \cdot \cdot 1$ & YN/GV & $\Delta T \Delta / \mu T$ & 1 & سبك منطقى & \multirow{3}{*}{ والدين } \\
\hline$\cdot / F F \Delta$ & $\cdot / \Delta \Lambda$ & $Q / \Lambda Y$ & 1 & سبك تكانشى & \\
\hline$\cdot / 1 \wedge 9$ & $1 / V V$ & $r \cdot 19 Y$ & 1 & سبك اجتنابى & \\
\hline
\end{tabular}

مقدار آماره F براى بررسى تفاوت بين گروه آزمايش و كواه در

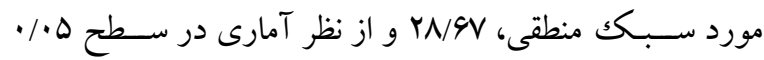

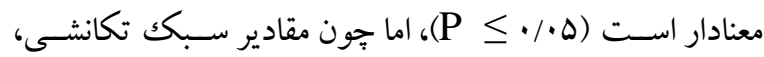

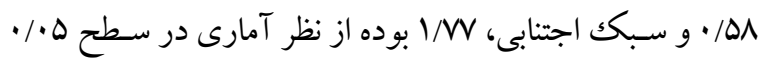

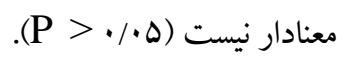
جـدول ه، آزمون اثر درون كروهى خرينهاوس-كيسـر متغيرهاى سبك منطقى، سبك تكانشى، و سبك اجتنابى را براى إن بررسى تفاوت كلى اندازهيرىها در طول زمان نشان مىدهد.
همـان كونه كه در جدول \& مشــاهده مى شـــود طبق كزارش

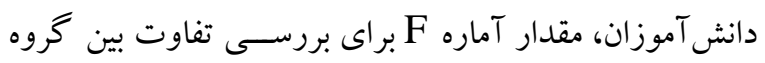

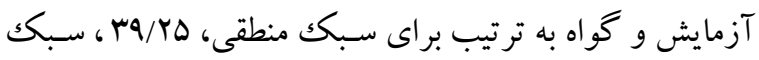

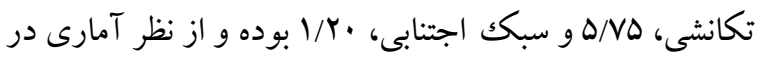

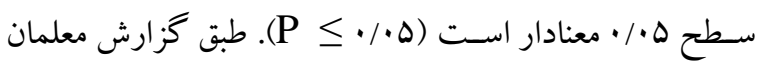

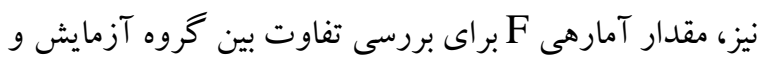

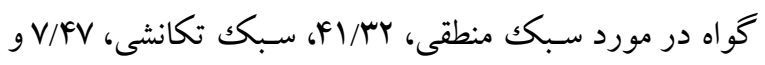

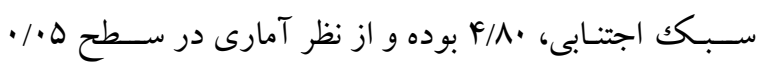
معنادار است (ه•/P

جدول 0: آزمون اثر درون كروهى كرينهاوس-كيسر متغيرهاى سبك منطقى، سبك تكانشى، و سبك اجتنابى براى بررسى تفاوت كلى اندازهكيرىها در طول زمان

\begin{tabular}{|c|c|c|c|c|c|c|}
\hline سطح معنادارى & $\mathbf{F}$ & مجذورات ميانكين & درجه آزادى & متغير وابسته & منبع تغييرات & \\
\hline$\% r$ & $1 . / 11$ & $r V r / v I$ & $1 / .9$ & سبك منطقى & زمان & \\
\hline$\% r$ & $\Lambda / \wedge \Delta$ & $r \cdot r / v q$ & $1 / 11$ & سبك تكانشى & (ييش آزمون، بِ آزمون و & \\
\hline $1.4 q$ & ه/l & $\Delta r / T V$ & $1 / r$. & سبك اجتنابى & يبيخيرى) & \\
\hline$\% \cdot 1$ & $r q / r q$ & $119 \cdot / 11$ & $1 / \cdot 1$ & سبكك منطقى & 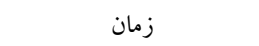 & \\
\hline$\%$ r Y & $k / Y q$ & $\mid q / \cdot 1$ & $1 / \Delta r$ & سبك تكانشى & (ييش آزمون، يس آزمون و & معلمان \\
\hline$\cdot / T V r$ & I/r & $r \& / 0 \Lambda$ & $1 / \cdot r$ & سبك اجتنابى & ي קيخيرى) & \\
\hline$\% / .4$ & $\Lambda / r)$ & $M T \Delta / \varphi q$ & $1 / \cdot \cdot$ & سبك منطقى & زمان & \\
\hline V/YYA & $1 / 4 \Lambda$ & $r F / I T$ & $1 / \cdot 1$ & سبك تكانشى & (ِيش آزمون، يٍ آزمون و & 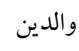 \\
\hline$\cdot / \cdot 11$ & $r / l f$ & $91 / 0$. & $1 / \cdot \cdot$ & سبكك اجتنابى & بي بيخيرى) & \\
\hline
\end{tabular}

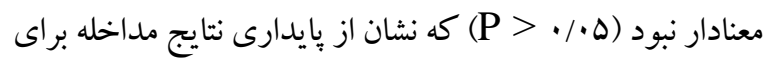
ســـك اجتنـابى در طول زمـان دارد. طبق گز ارش والـدين نيز، مقدار آماره F براى بررسـى تفاوت سـبك منطقى در زمانهاى

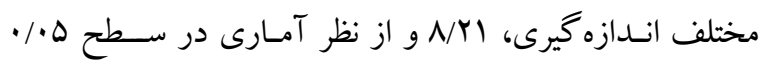

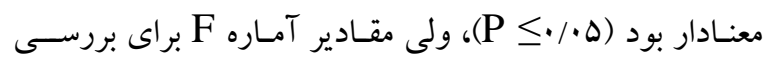

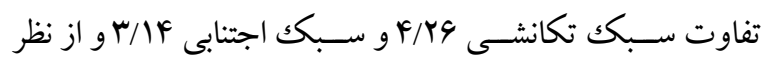

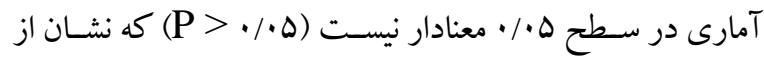

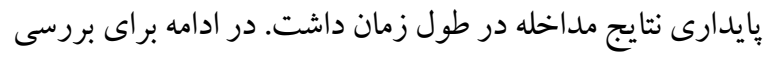

بر طبق كزارش دانش آموزان ، مقدار آماره F براى بررسى

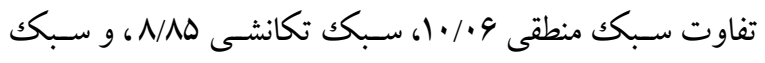
اجتنابى سا/ه در زمانهاى مختلف اندازه كيرى از نظر آمارى در

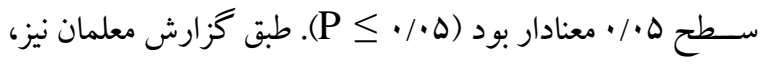
مقـادير آماره F براى بررسـى تفاوت ســـك منطقى

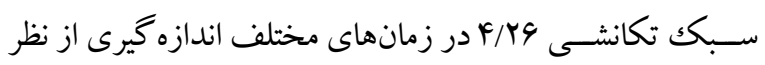

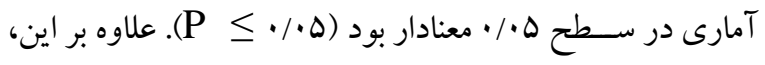
مقدار آماره F براى بررسى تفاوت سـبك اجتنابى در زمانهاى

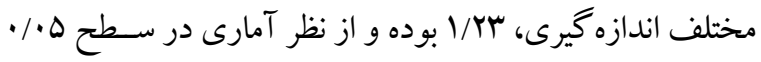


محـل دقيق تفــاوت، از آزمون تعقيقبى LSD اســتفــاده شــــ

\begin{tabular}{|c|c|c|c|c|}
\hline سطح معنادارى & تفاوت ميانكينها & محل تفاوت & متغير وابسته & \\
\hline$\cdot / \Delta r$ & $-\cdot / 4$ & يِيگيرى-يس آزمون & & \\
\hline$\% r$ & r את/r & پِ آزمون-يش آزمون & سبك منطقى & \\
\hline$\% \mu$ & r/ar & يِيخيرى-ييش آزمون & & \\
\hline$\cdot / 1 \cdot v$ & $\cdot / \& \Delta$ & يِيخيرى-بس آزمون & & \\
\hline$\% r$ & $-Y / 90$ & يִ آزمون-ِيش آزمون & سبك تكانشى & دانش آموزان \\
\hline$\cdot \cdots v$ & $-Y / Y$. & بيخيرى-ييش آزمون & & \\
\hline.$/ 114$ & $-\cdot / 4$ & بيگيرى-يس آزمون & & \\
\hline ( & $-\cdot / 94$ & يس آزمون-يش آزمون & سبك اجتنابى & \\
\hline.$/ \cdot Y \Lambda$ & $-1 / \mu$ & بيّيرى-يش آزمون & & \\
\hline.$/ 11 \mathrm{~V}$ & 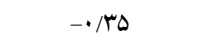 & يِيخيرى-يس آزمون & & \\
\hline$\cdot \cdots 1$ & $\cdot / 9 F$ & يس آزمون-يش آزمون & سبكك منطقى & \\
\hline$\cdot / \cdot 1$ &.$/ 94$ & يِيَيرى-ِيش آزمون & & \\
\hline.$/ 194$ & $\cdot / 41$ & يِيخيرى-يس آزمون & & \\
\hline 每/. & $\cdot / 4$ & پس آزمون-يش آزمون & سبك تكانشى & معلمان \\
\hline.$/ 10$ & $\cdot / \wedge \Delta$ & يِيخيرى-ييش آزمون & & \\
\hline . MAr &.$/ 1$ & يِيَيرى-يس آزمون & & \\
\hline - MFF & $-\cdot / \wedge \vee$ & پس آزمون-ييش آزمون & سبكك اجتنابى & \\
\hline$\cdot / r \cdot 4$ & $-\cdot / V V$ & 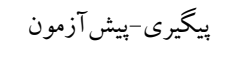 & & \\
\hline.$/ 109$ & $-\cdot / \cdot v$ & يِيَيرى-يس آزمون & & \\
\hline$\% \cdot \Delta$ & r/qr & يس آزمون-ييش آزمون & سبك منطقى & \\
\hline.$/ .49$ & r/AG & بيخيرى-ييش آزمون & & \\
\hline.$/ 19 \mathrm{~V}$ & $-\cdot / \cdot 1$ & بيخيرى-يس آزمون & & \\
\hline$\cdot / r \Delta$. & $-\cdot / M$ & پِ آزمون-يش آزمون & سبك تكانشى & و الدين \\
\hline$\cdot / r \cdot 9$ & $-\cdot / 9 V$ & يِيخيرى-ييش آزمون & & \\
\hline . /Ar & $-\cdot / \cdot \Delta$ & يِيَيرى-يس آزمون & & \\
\hline$\cdot / \cdot 19$ & $-1 / Y Y$ & يس آزمون-ييش آزمون & سبك اجتنابى & \\
\hline$\cdot / \cdot \mathrm{VA}$ & $-1 / 1 V$ & يِيَيرى-يش آزمون & & \\
\hline
\end{tabular}

مى توان كفـت كـه نتـايج مـداخله در مرحله بيخيرى، همجنان

$$
\text { يايدار باقى مانده است. }
$$

\section{بحث و نتيجه تيرى}

هدف يُزوهش حاضر بررسى تاثير آموزش حل مسئله خانو اده/ مدرســهحور بر سـبككهاى حل مســـله دانش آموزان دوره ابتدايى بود. نتايج طبق گزارش دانش آموزان، والدين و معلمان،
جدول 9، نتايج آزمون تعقيى LSD را براى بررسى محل تفاوت متغيرهاى سـبك منطقى، سـبك تكانشـى، و سـبك اجتنابى در طول زمان را طبق گزارش دانش آموزان، معلمان، و والدين نشـان مىدهد. بر اين اسـاس همان كونه كه مشـاهده مىشـــود، طبق كزارش دانش آموزان، معلمـان، و والـدين در تمامى زيرمقياس هاى حل مسئله تفاوت ميانخين هاى بس آزمون - بيكيرى از لحاظ آمارى، معنادار نبود (ه •/ P P)؛ بنابراين 
راسـتاى نتايج يزوهش حاضـر، بعضسى از مطالعات بر ارزيابى

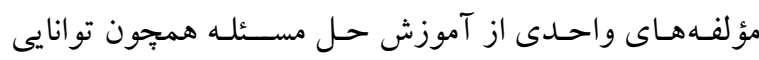

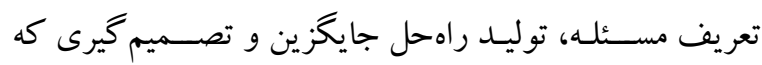
تبيين كننده سبك حل مسله منطقى است، متمركز شدهاند (If) 19 و IV). كو تـه و همكاران (II) نيز در يزووهشسى بـا عنوان

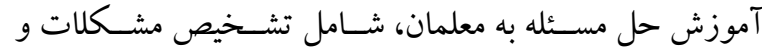

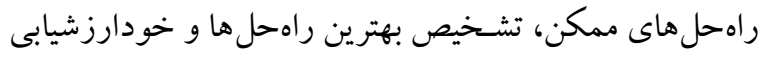

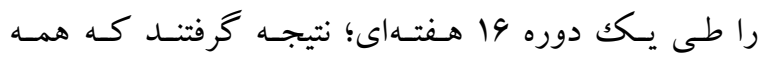

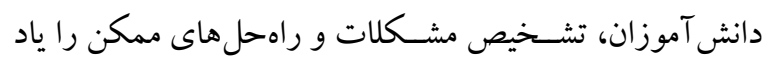
كرفتند و علاوه بر اين، مهارت هاى حل مسـئله راطى جلسـات

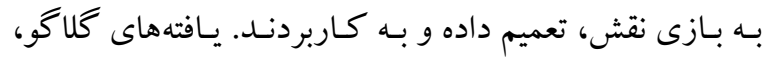

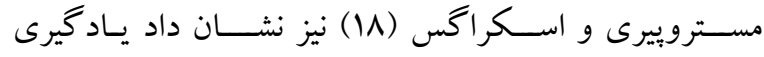

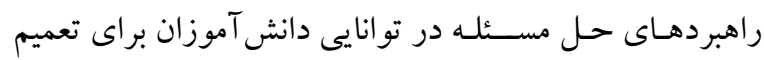

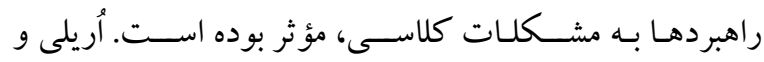

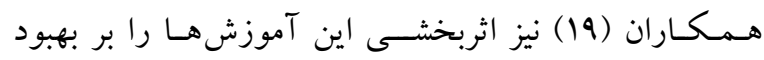
مهارت هـاى مقـابله منطقى كودكـان، تـأييد كردهانــ. نتايج يُزوهش شـور (به نقل از ها 1) نشان داد كود كانى كه احساسات

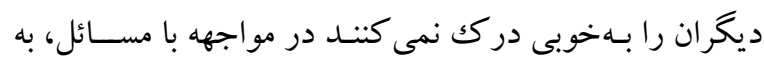
راهحل هاى جايگزين و ويامد رفتار خود فكر نمى كنند و بيشـتر

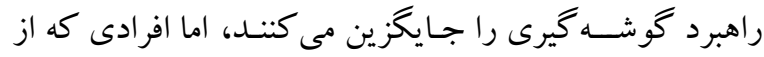
توانـايى حل مســئله برخوردارند مى تو انند راهحل هاى منطقى

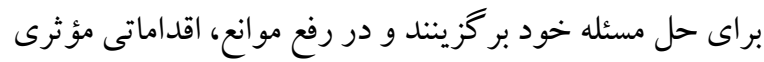
و بهنخامى رادر نظر مى گيرند. در همين راسـتا و همسـو با نتايج يزوه هش حاضسر نتايج يُزوهشهاى متعدد ديخر بر روى گرووهاى مختلف سنى نشان

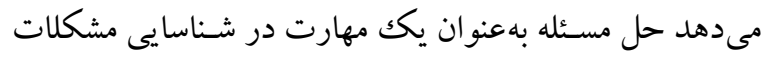
و راهحل هـاى بـالقوه، به افراد كمكك كرده و باعث مى شــــود راهحل هاى ممكن، بهدقت مطالعه و مناسب ترين آنها با شر ايط فرد، انتخاب و اجرا شـودد و درنهايت در موقعيتهاى مختلفى

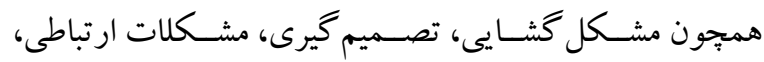
رفتارى، تحصـيلى، و مديرت بحران، نقش تعديلكر ايفا كنند

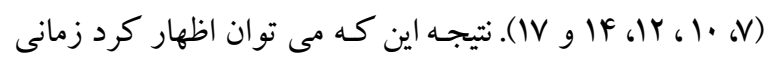

حـاكى از آن اسـت كـه آموزش برنامه حل مســئله خانوادها مدرســهحور در دانش آموزان باعث افزايش توان و بهبود در

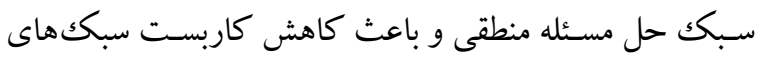

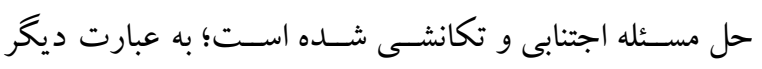

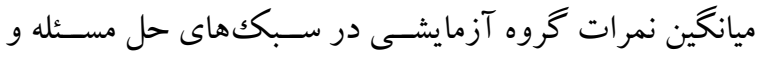
زيرمقياسهاى آن طبق گزارش دانش آموزان، والدين و معلمان در مرحله يس آزمون در مقايسـه با مرحله يِيش آزمون، افزايش

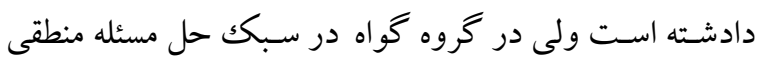

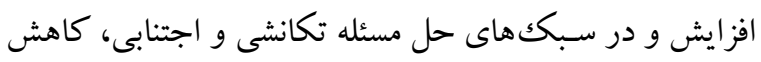

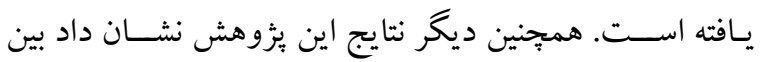

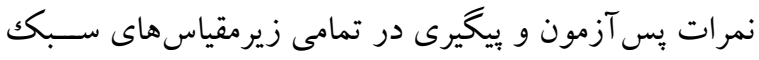

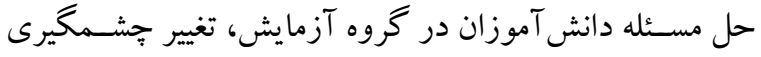

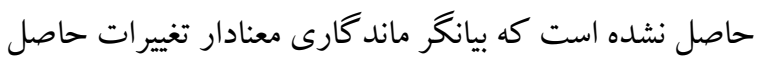

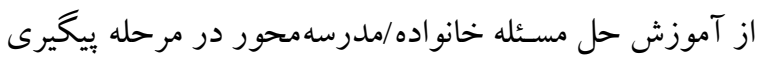
اسـت. اين يافتها با بخشى از نتايج ساير بزوهش ها همسو است

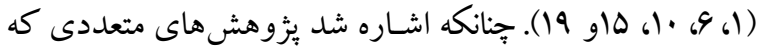
در رابطه با آموزش حل مسئلهمحور و نقش آن در شاخصهاى

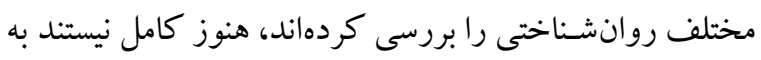
همين دليل ضـرورى اسـت علاوه بر بررسى كاركرد حل مسئله بر متغيرهاى روانشـناختى منفى بر شـاخصهاى روانشـناختى مثبت از جمله سـبككهاى مسـئله كشـايى نيز تمركز بيشـترى از

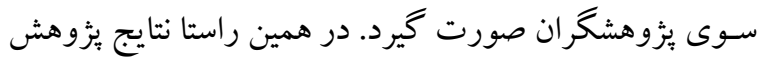

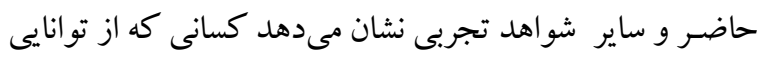
حل مسـئله منطقى برخوردار نيسـتند، زمانى كه با مانعى برخورد

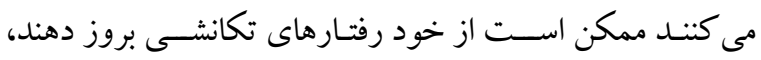

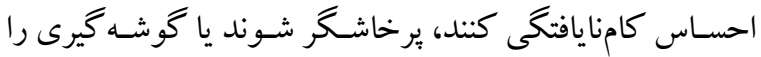

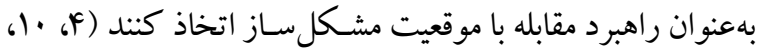
الو 11). همسـو با نتايج يزوهش حاضسر شواهد تجربى متعدد

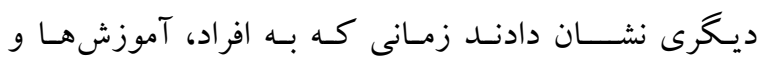
دسـتور العمل هاى صـريح و آشـكارى درباره فرايند تعريف و بيان مسـئله ارائه مىشود، بيشرفت فراوانى در كميت و كيفيت وليت

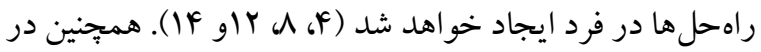


آموزش حل مسئله خانو اده/ مدرسهحور به صورت همزمان بر

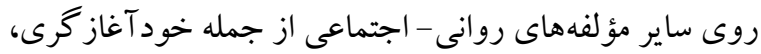

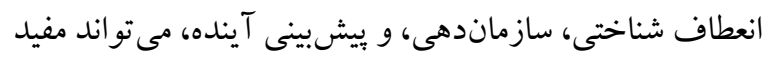

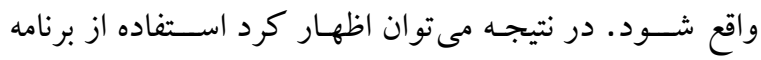
آموزش حل مسئله رامىتوان به عنوان يكك مداخله كار آمد در

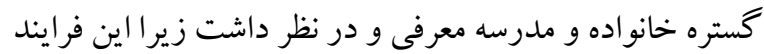
با ارايه راهكارهاى عملى به صــورت مســتقيم و غيرمسـتقيم

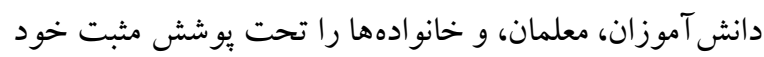

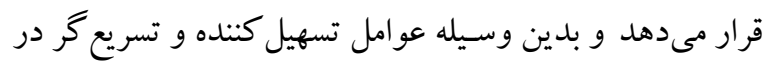

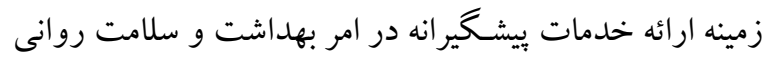
افراد جـامعـه بـه ويزه كودكـان و نوجوانان فراهم مى آورد كه نتايج يزوهش حاضر نيز اين موضوع را يشتيبانى كرده است. از

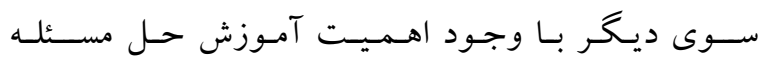
خانواده/مدرسهمحور مىتوان بيان كرد كه راهبردهاى حل مسئله،

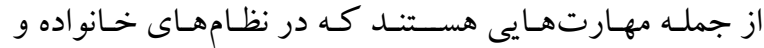
آموزشويرورش كشـورمان كمتر مورد توجه قراركر فته است، درحسالى كـه اين مهارت در كـاهش تعـارضهــا و مشــكلات بين فردى و درونفردى نقش اساسى دارند.

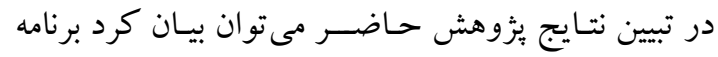

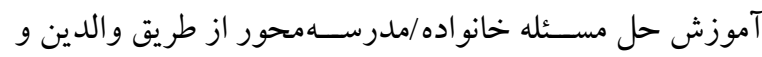
معلمان براى كودكان و نوجوانان بر اساس ايده و الكوى "بايد جُكونه فكر كردن را به كودك و نوجوان آموخت"، اســتوار اسـت. اين الكوى شـناختمحور باعث مىشـود تا كود كان و نوجوانـان در مواجهه با موقعيتهاى مختلف اجتماعى در خانه و مدرســه از كاركرد عالى ذهنى بهرهمند شــوند و به دور از

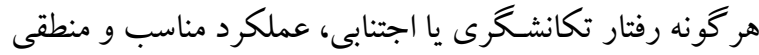

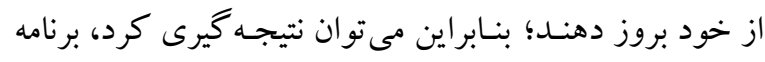
حل مسـئله خانو اده/مدرسـهمحور در جهت يارى به كودكك و نو جوان و ايجاد فرصتى مناسب براى تحول شناختى و اجتماعى

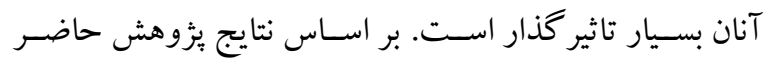

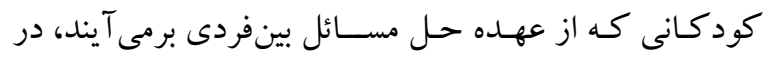

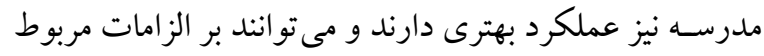

كه والدين يا معلمان به تكنيك هاى حل مسئله آكاهى دارند و

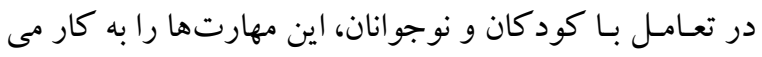

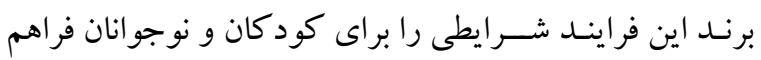

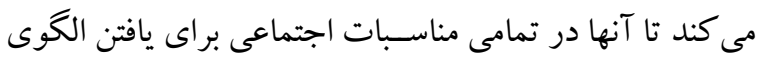
ياسخ هاى مقابلهاى موثر، تلاش كنند و از ياسخ هاى هيجانى يا

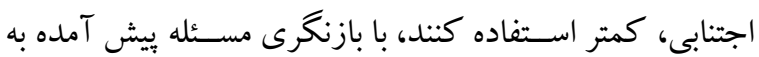

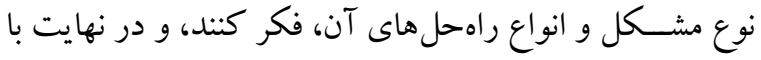
مسـئله روبرو شـوند و بهترين راه حل را براى حل آن انتخاب

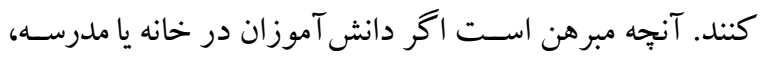

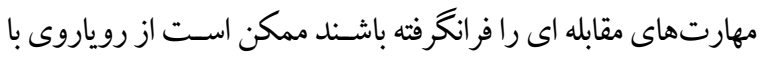
مشـكل اجتناب كنند و يا راهبرد تهاجمى اتخاذ كنند. در همين راسـا نتايج يثزوهش حاضر مشخص كرد كه از طريق آموزش والدين و معلمان و مجهز كردن آنها به مهارت هاى حل مسئله، نســـهـ هاى شــناختى كود كان و نوجو انان به ســمت اتخاذ تصسميمهاى منطقى از جمله توافق، مصـالحه يا مذاكره هدايت

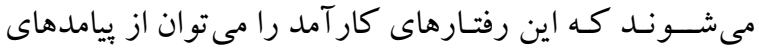
آموزش حل مسئله خانو اده/ مدرسهمحور قلمداد كرد.

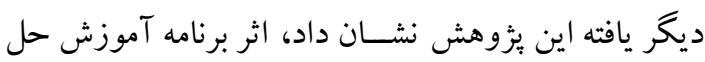

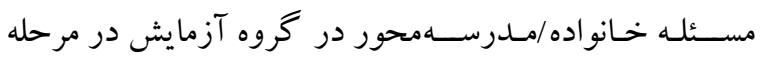

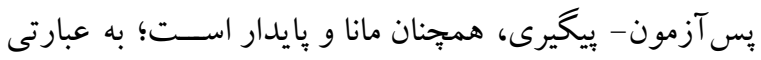

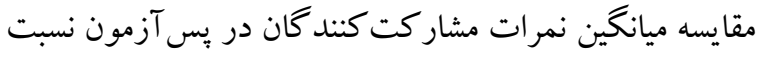

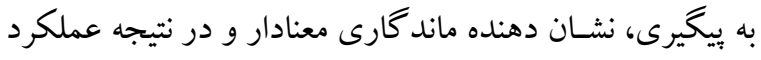

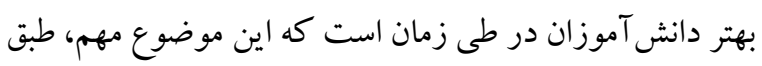
كزارش مشـار كت كنند كان، معلمان، و والدين بشـتيبانى شـــه است كه در نوع خود، يكك يافته مهم تلقى مى شود. با توجه به اين يافته يزوهشسى و سـاير شـواهد تجربى اشـاره شـده مبنى بر

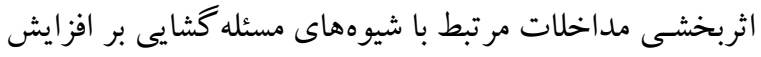

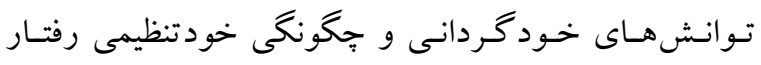
دانش آموزان و همجنين با توجه به اين موضسوع كه اثربخشى

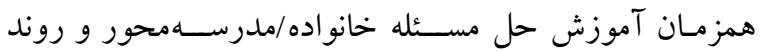

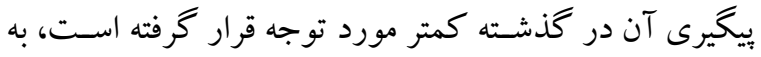
نظر مىرسـد كه انجام يُزوهش هاى بيشـتر در زمينه اثربخشى 
شناختى-رفتارى در كود كان و نوجو انان در جامعه هدف فر اهم آورده و مى تو اند بر اي يزوهشخُ ان علاقه مند حوزه

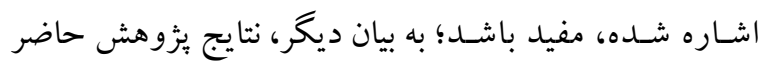
نشان مىدهد كه كود كان و نوجوانان آموزش ديده در مهارت حل مســئلهحور در مواجهه با رخدادهاى تنش آور وابسـته به نقش خود، بـه ويزه در خانه و مدرســه از الكوى مســئلهمدار

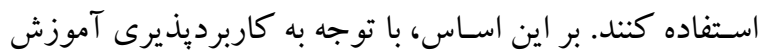

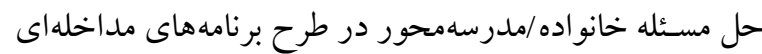

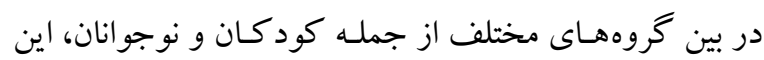
مطالعه از لحاظ كاربردى، حائز اهميت فراوانى اسـت. بنابراين،

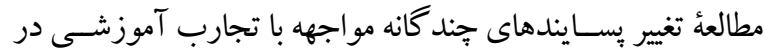
بين كود كان و نوجوانان و سـلامت روانشناختى آنان به مثابه نتيجه

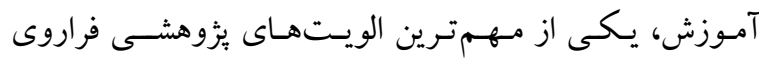

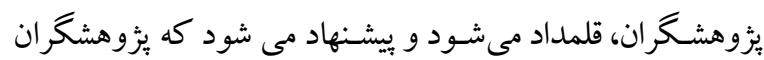

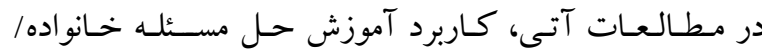
مدرسهمحور را در گروه هاى مختلف سنى با در نظر داشتن عامل جنسيت مورد توجه قرار دهند. همجنين سازمان آموزش و يرورش

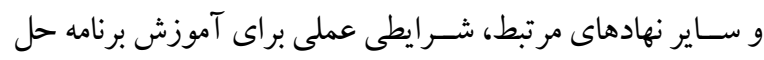
مسئله به والدين و معلمان را فر اهم كنند.

تقدير و تشـكر: مقاله حاضـر مستخرج از طرح يزوهشى (كد V. (I)

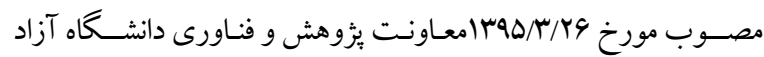
اسـلامى واحد كرمانشـاه اسـت. بدين وسـيله از حمايت حوزه معاونت

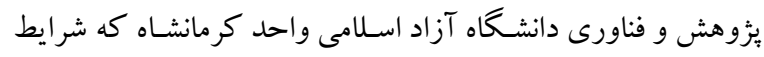

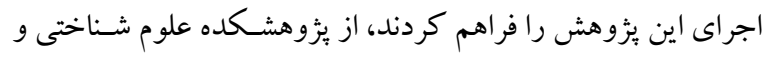

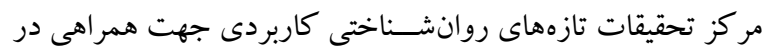

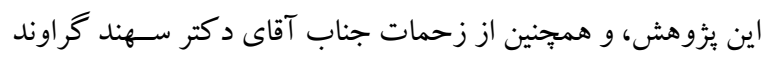

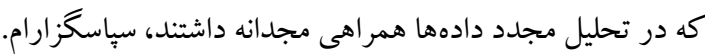
تضــاد منافع: اين بزوهش براى نويســده هيج گونه تضـاد منافعى ايجاد نكرده است.
بـهـ تكـاليف مدرســاى تمركز بيشــترى داشــته باشــند. در بررسىهاى مختلف، بسـيارى از روانشــاسـان، مشـاوران، و مدد كار ان اجتماعى بر تأثير مثبت برنامههاى آموزش حلى حل مسئله

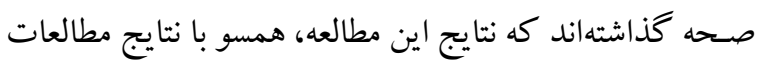
قبلى اسـت. همجنين بر اساس يافته هاى حاصل از اين يُزوهش مى توان بيان كرد آموزش مهارتهاى حل مسـئله با روى آورد شناختى - رفتارى در كود كان و نوجوانان، توانمندى شناختى و

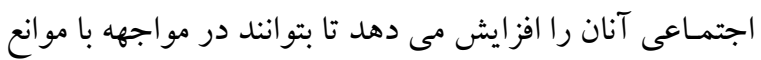

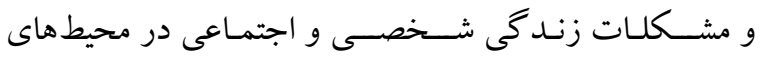
اجتماعى، از جمله مدرسه و خانواده، از مهارت هاى حل مسئله

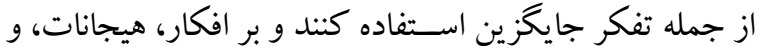
رفتار خود تسـلط داشـته باشند. همان طور كه بيشتر اشاره شد، يثزوهش حاضـر ضـمن اطلاع از ضـرورت مطالعه و بازشـناسى

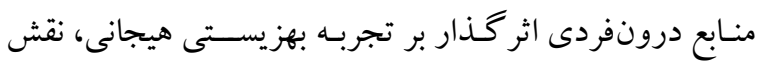

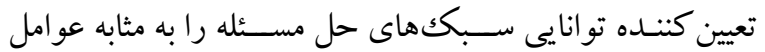
درونفردى اثر كذار بر بهزيستى، در كودكان و نوجو انان مورد

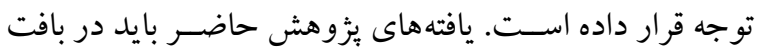

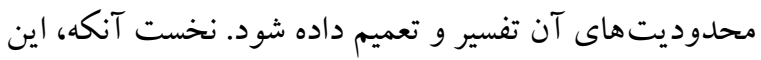
مطالعه نيز مانند بسـيارى از مطالعات ديخر به دليل اســفاده از

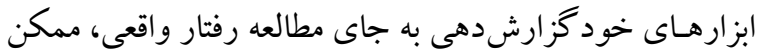

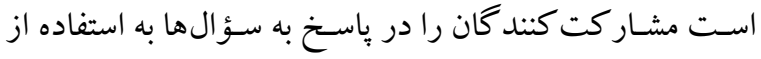
شـيوههاى مبتنى بر كسـب تأييد اجتماعى و اجتناب از بدنامى

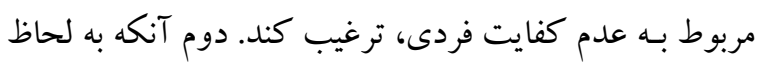
محدوديت هاى اجرايى، امكان در نظر خرفتن مدت زمان فرمان بيشتر

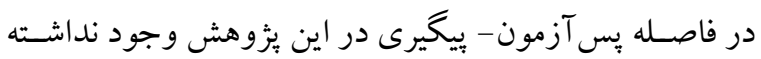

در مجموع، يزوهش حساضــر در قلمرو مطـالعـات موجود

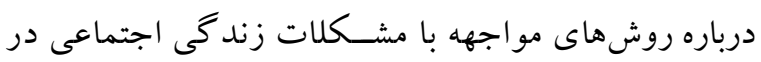

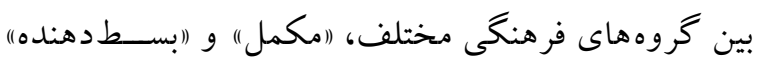
تلقى مى شود. يافته هاى اخير، شواهد تجربى تازهاى درباره آموزش حل مســئله خانواده/مدرســهمور با روى آورد 


\section{References}

1. Smetana JG, Rote WM. What do mothers want to know about teens' activities? Levels, trajectories, and correlates. J Adolesc. 2015; 38: 5-15. [Link]

2. Cakir M. Investigating prospective teacher`sperceived problem solving abilities in in relation to gender, major, place lived and locus of control. Universal Journal of Educational Research. 2017; 5(6): 10301038. [Link]

3. D'Zurilla TJ, Nezu AM. Problem-solving therapy: a positive approach to clinical intervention. 3 Edition. New York, NY: Springer Publishing Company; 2007, pp: 1- 317. [Link]

4. Bell AC, D'Zurilla TJ. Problem-solving therapy for depression: A meta-analysis. Clin Psychol Rev. 2009; 29(4): 348-353. [Link]

5. Ozdemir Y, Kuzucu Y, Koruklu N. Social problem solving andaggression: the role of depression. Journal of Psychologists and Counsellors in Schools. 2013; 23(1): 72-81. [Link]

6. Safi A. Education, elementary, junior high and high school. Tehran: Samt press; 2007, pp: 1-238. [Presian].

7. Levitt JM, Saka N, Roamanelli LH, Hoagwood K. Early identification mental health problem in schools. J Sch Psychol. 2007; 45(2): 163-191. [Link]

8. Shokoohi-Yekta M, Zamani N. The effectiveness of cognitive interpersonal problem-solving on reducing challenging behaviors of slow-learner students: single-subject study. Journal of Psychological Models and Methods. 2012; 2(8): 55-71. [Presian]. [Link]

9. Shokoohi-Yekta M, Parand A, Dargahi M. Family-based preventive interventions: effects on parent-child relationship and parenting styles. Journal of Child Mental Health. 2016; 3(2): 55-63. [Presian]. [Link]

10. Fusaro M, Smith MC. Preschool inquisitiveness and science- relevant problem solving. Early Child Res Q. 2018; 42: 119-127. [Link]

11. Cote D, Pierce T, Higgins K, Miller S, Tandy R, Sparks S. Increasing skill performances of problem solving in students with intellectual disabilities. Educ Train Autism Dev Disabil. 2010; 45(4): 512-24. [Link]

12. Carr A. Family therapy: concepts, process and practice. 3rd ed. Wiley-Blackwell, John Wiley \& Sons; 2012, 552 p. [Link]

13. Austad CS. Counseling and psychotherapy today: theory, practice and research. New York: McGrawHill Higher Education; 2009, 541p. [Link]

14. Shaw EJ, Selby EC, Houtz JC. Problem solving style and beliefs about teaching, learning, and problem solving. Creat Res J. 2009; 21(4): 394-399. [Link]

15. Shokoohi Yekta M, Davaei M, Zamani N, Poorkarimi J, Sharifi A. The efficacy of "i can problem solve" program in improving problem solving and social skills amongst preschoolers and first grade students. Advances in Cognitive Science. 2013; 15(3): 82-73. [Presian]. [Link]

16. D'Zurilla TJ, Nezu AM, Maydeu-Olivares A. Social problem-solving inventory-revised (SPSI-R): technical manual. North Tonawanda, NY: Multi-Health Systems Inc. (MHS); 2002. [Link]

17. Siu AMH, Shek DTL. Relations between social problem solving and indicators of interpersonal and family well-being among Chinese adolescents in Hong Kong. Soc Indic Res. 2005; 71(1-3): 517-539. [Link]

18. Glago K, Mastropieri MA, Scruggs TE. Improving problem solving of elementary students with mild disabilities. Remedial Spec Educ. 2009; 30(6): 372-380. [Link]

19. O'Reilly MF, Lancioni G, Gardiner M, Tiernan R, Lacy C. Using a problem-solving approach to teach classroom skills to a student with moderate intellectual disabilities within regular classroom settings. Intl J Disabil Dev Educ. 2002; 49(1): 95-104. [Link] 